\title{
KONSTRUKSI LEVEL PENGETAHUAN METAKOGNITIF DALAM PEMBELAJARAN AGAMA HINDU
}

\author{
Oleh \\ Putu Sabda Jayendra \\ Dosen Sekolah Tinggi Pariwisata Bali Internasional (STPBI) Denpasar \\ Email:sabda@stpbi.ac.id
}

\begin{abstract}
ABSTRAK
Pengetahuan metakognitif merupakan aspek pencapain kecakapan level abstraksi tertinggi dalam dimensi pengetahuan. pengetahuan metakognitif merupakan tingkat teratas dalam susunan Taksonomi Bloom Revisi. Konstruksi pengetahuan level metakognitif merupakan kemampuan untuk mengetahui dan menyadari diri sendiri, dan mencakup pula kecakapan strategi kognitif melalui berpikir multiperspektif, serta multidimensional. Konstruksi pengetahuan metakognitif dalam pembelajaran agama Hindu memiliki urgensi untuk dilakukan untuk menciptakan karakter individu peserta didik yang tidak terjebak pada pemahaman dogmatis, bijaksana, serta mampu mewujudkan tatanan religi dan sosio-kultural masyarakat yang harmonis.
\end{abstract}

Kata Kunci: pengetahuan metakognitif, pembelajaran, agama Hindu.

\section{ABSTRACT}

Metacognitive knowledge is an aspect in achieving the highest level of abstraction skill in knowledge. It is also the highest level in Revised Bloom Taxonomy. The knowledge construction of metacognitive level is the ability to know and realize oneself, including the skill of cognitive strategy through multi-perspective and multi-dimensional thinking. The construction of metacognitive knowledge in Hindu as subject has the urgency in order to create the character of an individual learner which do not influenced by dogmatic thinking, wise, and is able to actualize the religious order and harmonic sosio-cultural people.

Keywords: metacognitive knowledge, learning, Hindu religion.

\section{PENDAHULUAN}

Pendidikan merupakan suatu proses pemanusiaan manusia dengan tujuan untuk mengangkat harkat dan martabat manusia itu sendiri dengan menjadikannya lebih beradab. Kata pendidikan berasal dari bahasa Yunani yaitu "pedagogik". Pedagogik berasal dari kata Yunani "paedos" yang berarti anak lakilaki dan "agogos" yang artinya mengantar, membimbing. Jadi pedagogik secara harfiah berarti pembantu anak laki-laki pada zaman Yunani kuno yang pekerjaannya mengantarkan anak majikannya ke sekolah. Kemudian secara kiasan pedagogik adalah membimbing anak ke arah tujuan hidup tertentu (Sadulloh, 2011:2).
Menurut Ki Hadjar Dewantara (Mahfud, 2008:33) pendidikan umumnya berarti daya upaya untuk memajukan bertumbuhnya budi pekerti (kekuatan batin, karakter), pikiran (intelek), dan tubuh anak. Sejalan dengan pengertian tersebut, Pasal 1 UndangUndang Republik Indonesia Nomor 20 Tahun 2003 tentang Sistem Pendidikan Nasional menyebutkan bahwa pendidikan adalah usaha sadar dan terencana untuk mewujudkan suasana belajar dan proses pembelajaran agar peserta didik secara aktif mengembangkan potensi dirinya untuk memiliki kekuatan spiritual keagamaan, pengendalian diri, kepribadian, kecerdasan, akhlak mulia, 
serta keterampilan yang diperlukan dirinya, masyarakat, bangsa dan negara (Rohman, 2011:10). Pernyataan tersebut menegaskan bahwa pendidikan tidak hanya bertujuan untuk menggali dan mengembangkan potensi dan kecerdasan peserta didik, namun juga yang lebih ditekankan adalah pembentukan kepribadian serta penanaman nilai-nilai budaya demi terbentuknya manusia yang memiliki moral dan akhlak mulia.

Pendidikan selain mencakup proses transfer dan transmisi ilmu pengetahuan juga merupakan proses yang sangat strategis dalam menanamkan nilai dalam rangka pembudayaan anak manusia. Terkait dengan hal tersebut, maka Mahfud (2008: 34) mengemukakan beberapa konsep pendidikan yakni:

1. Suatu proses pertumbuhan yang menyesuaikan dengan lingkungan.

2. Suatu pengarahan dan bimbingan yang diberikan kepada anak-anak dalam pertumbuhannya.

3. Suatu usaha sadar untuk menciptakan suatu keadaan atau situasi tertentu yang dikehendaki oleh masyarakat.

4. Suatu pembentukan karakter, kepribadian, dan kemampuan anakanak dalam menuju kedewasaan.

Beranjak dari konsep tersebut, dalam kajian pendidikan agama Hindu, esensi dari pendidikan adalah membentuk peserta didik yang memiliki pemahaman mendalam akan Tattwa, Susila, dan Acara. Tattwa dalam arti paham akan filosofi atau intisari ajaran agama, Susila dalam artian memiliki kepribadian, etika, dan budi pekerti, dan Acara, yaitu mampu berperan aktif dalam kegiatankegiatan keagamaan, umumnya di masyarakat. Selain itu, dalam cakupan aspek yang lebih tinggi, peserta didik juga diharapkan mampu memahami pengetahuan yang bersifat para widya (cakupan pengetahuan yang bersifat kerohanian) dan apara widya (cakupan pengetahuan yang bersifat keduniawian atau saintis), serta mampu menggeneralisasinya sebagai suatu pemahaman yang utuh.

Apabila dilihat dari pemahaman tujuan di atas, secara esensi pendidikan agama Hindu bersifat sangat sakral. Manusia yang mampu menjadi manusia seutuhnya adalah manusia yang mampu membangun harmonisasi antara manusia dengan Tuhan (Ida Sang Hyang Widhi Wasa), manusia dengan sesama manusia, dan manusia dengan alam lingkungannya. Oeh sebab itulah dalam tinjauan pendidikan agama Hindu, pencapaian level pengetahuan dan pemahaman peserta didik tidak hanya terpaku pada pencapaian level pemahaman kognitif, namun yang terpenting adalah pencapaian hingga level metakognitif.

Pengetahuan metakognitif merupakan pengetahuan dalam level abstraksi tinggi. Artinya, kemampuan kognitif telah mampu melakukan generalisasi dari setiap informasi yang diperoleh. Pengetahuan metakognitif merupakan kecakapan yang mencakup kemampuan berpikir dengan melibatkan kognitif/intelektual, emosional, dan spiritual yang pada akhirnya menentukan tindakan dan pengontrolan perilaku individu. Dalam konteks pembelajaran, kemampuan metakognitif merupakan kesadaran seseorang tentang bagaimana ia belajar, kemampuan untuk menilai kesukaran sesuatu masalah, kemampuan untuk mengamati tingkat pemahaman dirinya, kemampuan menggunakan berbagai informasi untuk mencapai tujuan, dan kemampuan menilai kemajuan belajar sendiri (Flavel dalam Indarini dkk, 2013:41).

Apabila dikaitkan dengan konteks pembelajaran agama, khususnya agama Hindu, maka level pengetahuan metakognitif meliputi kesadaran akan bagaimana belajar untuk memahami apa yang diyakini, memahami hakikat diri, baik secara individu, sosial, dan sebagai bagian dari komponen alam semesta, dan bertindak dengan pertimbangan 
dari berbagai aspek dan informasi, terutama aspek rasionalitas dan spiritualitas yang tergeneralisasi menjadi sebuah pemahaman yang utuh. Konstruksi pengetahuan hingga pencapaian level metakognitif sangat diperlukan. Fenomena yang terjadi kini, pemahaman mayoritas masyarakat Hindu masih terjebak pada pemahaman keyakinan yang masih bersifat dogmatis, etnosentris, belum mencerminkan karakter universalitas Hindu, serta belum tersistematisasi secara sempurna. Untuk menguatkan argumentasi tersebut fenomena yang tampak pada masyarakat Hindu di Bali kebanyakan masih terpaku pada otoritas dresta desa dan praktik acara agama Hindu namun masih kurang tergeneralisasi secara utuh dengan pemahaman Tattwa dan Susila. Hal inilah kerap menimbulkan kekakuan dalam praktik beragama, yang secara hakikat berpangkal pada kurangnya pemahaman tentang apa sesungguhnya esensi dari yang diyakini.

Berdasarkan pemaparan tersebut, arah pencapaian pengetahuan hingga level metakognitif mutlak diperlukan dan dimulai sedini mungkin. Membentuk aspek pengetahuan metakognitif memerlukan proses yang tidak instan, karena harus dimulai dari pemahaman level faktual, konseptual, prosedural, hingga mencapai level metakognitif. Oleh sebab itu, konsistensi dan kontinuitas sangat diperlukan guna tercapainya konstruksi pemahaman agama Hindu bagi peserta didik secara utuh yang belum diresapi dan diimplemetasi dengan baik pada tatanan religi dan sosio-kultural masyarakat Hindu, khususnya di Bali.

Satu hal yang harus digaris bawahi adalah konstruksi pengetahuan hingga level metakognitif dalam pendidikan agama Hindu bukanlah bertujuan untuk mendekonstruksi segala tatanan dresta yang ada dan telah mapan hingga mengakar kuat dalam masyarakat. Tujuan sesungguhnya agar setiap individu peserta didik mampu melihat perbedaan tatanan atau dresta (desa mawacara) tersebut sebagai satu kesatuan, dan satu kesatuan tersebut dapat ditempuh dengan banyak cara. Hal ini menjadi urgensi pembahasan yang dituangkan dalam rumusan masalah mengenai konsep, strategi, dan implikasi pengetahuan metakognitif dalam pembelajaran agama Hindu.

Dengan kata lain, semua menuju pada proses generalisasi karakter melalui berpikir dan memahami hakikat dan esensi dari yang diyakini dan dipelajari secara universal. Implikasinya, peserta didik diharapkan mampu menguatkan keyakinan tersebut dengan banyak cara, bahkan tanpa mengabaikan aspek rasionalitas, atau sebaliknya, berpikir rasional dengan melibatkan aspek rasa emosional dan spiritualitasnya.

\section{PEMBAHASAN}

\subsection{Konsep Pengetahuan Metakognitif}

Metakognitif berasal dari dua kata yang dirangkai yaitu meta dan kognisi (cognition). Meta berasal dari bahasa Yunani, dalam bahasa Inggris diartikan after, beyond, with, adjacent, adalah suatu prefik yang digunakan dalam bahasa Inggris untuk menunjukkan pada suatu abstraksi dari suatu konsep (Indarini, 2013:41). Sedangkan kognisi diartikan sebagai kemampuan berpikir. Dalam konsep pembelajaran umum, menurut Suherman (2001:95), metakognitif adalah suatu kata yang berkaitan dengan apa yang diketahui tentang dirinya sebagai individu yang belajar dan bagaimana dia mengontrol serta menyesuaikan perilakunya. Dengan kemampuan seperti ini seseorang dimungkinkan memiliki kemampuan tinggi dalam memecahkan masalah. Metakognitif adalah suatu kesadaran tentang kognitif diri sendiri, bagaimana kognitif bekerja serta bagaimana mengaturnya. Kemampuan ini sangat penting terutama untuk keperluan efisiensi penggunaan kognitif dalam menyelesaikan masalah. Secara ringkas 
metakognitif dapat diistilahkan sebagai "thinking about thingking" (Lidnillah, tt:4). Metakognitif merupakan dimensi baru dalam Taksonimi Bloom Revisi. Pada awalnya, taksonomi yang dikemukakan oleh Bloom hanya memuat proses atau level pencapaian konstruksi pengetahuan pada peserta didik yang meliputi; 1) Pengetahuan, 2) Pemahaman, 3) Aplikasi, 4) Analisis, 5) Sintesis, dan 6) Evaluasi (Widodo, 2005:62). Taksonomi Bloom kemudian direvisi oleh Anderson dengan nama Taksonomi Bloom Revisi. Taksonomi Bloom Revisi membagi konstruksi kecakapan dengan ditinjau dari dua dimensi yakni dimensi proses kognitif dan dimensi pengetahuan. dimensi proses kognitif meliputi; 1) Menghafal/mengingat (remember), 2) Memahami (understand), 3) Mengaplikasikan (apply), 4) Menganalisis (analyze), 5) Mengevaluasi (evaluate), dan 6) Mencipta (create). Sedangkan dimensi pengetahuan mencakup; 1) Pengetahuan Faktual, 2) Pengetahuan Konseptual, 3) Pengetahuan Prosedural, dan 4) Pengetahuan Metakognitif (Widodo, 2005:62). Kedua dimensi tersebut saling mengisi dan merinci satu sama lain sebagaimana dapat digambarkan dalam gambar berikut.

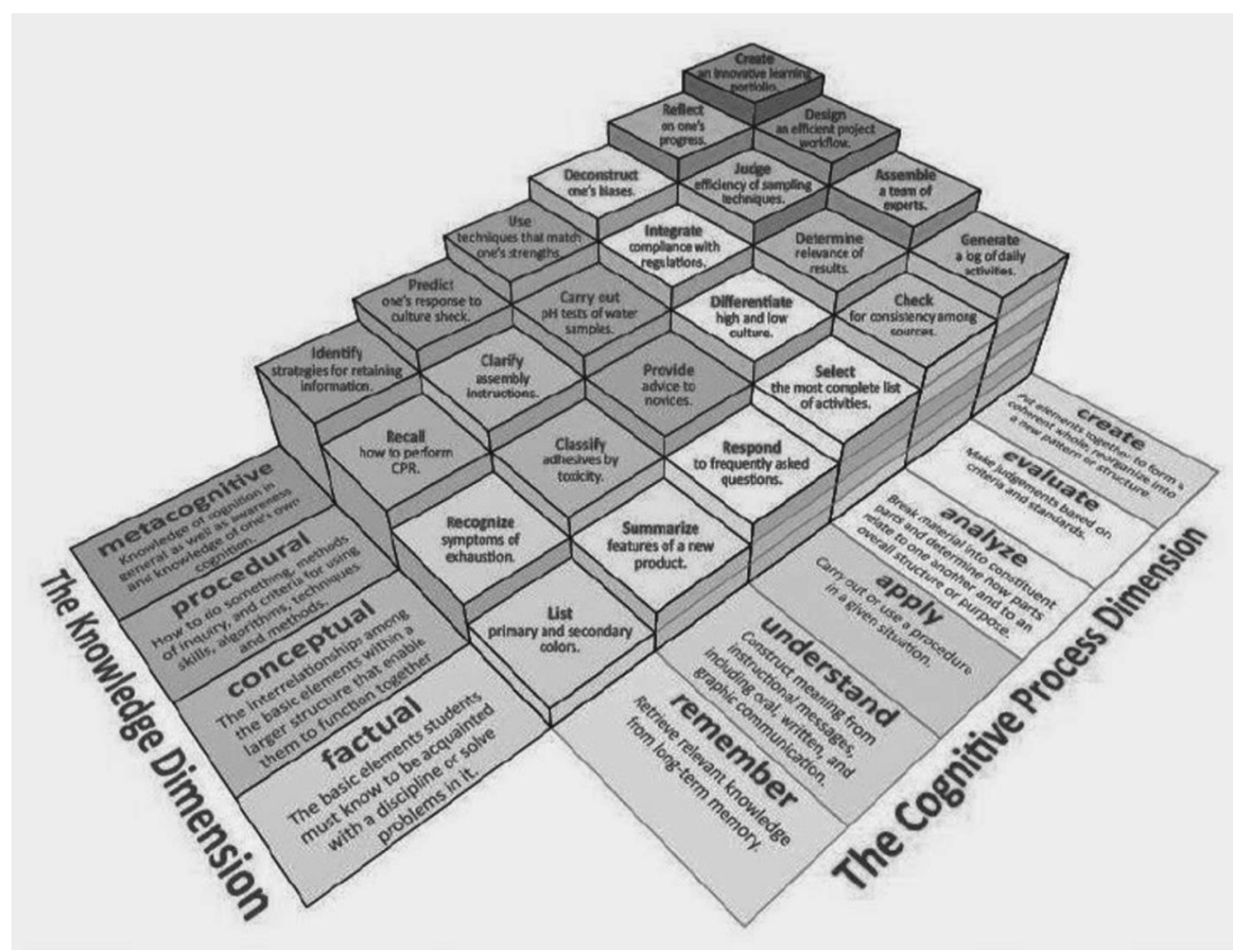

Gambar 2.1

Kombinasi Dimensi Proses Kognitif dengan Dimensi Pengetahuan Dalam Taksonomi Bloom Revisi. (Sumber: Heer, 2012, Gunawan dan Palupi, 2012:112).

Menyimak gambar tersebut, konstruksi metakognitif mencakup tiga pengetahuan metakognitif merupakan pengetahuan, yaitu; 1) pengetahuan strategis, pencapaian level tertinggi yang harus dicapai 2) pengetahuan tentang tugas kognitif, dan dalam rangka konstruksi pengetahuan peserta didik secara keseluruhan. Lebih jauh, Flavell (dalam Indarini, 2013:41) menyatakan bahwa 3) pengetahuan diri. Pengetahuan strategis adalah pengetahuan tentang strategi-strategi belajar dan berpikir serta pemecahan 
masalah. Subjenis pengetahuan ini mencakup pengetahuan tentang berbagai strategi yang dapat digunakan siswa untuk menghafal materi pelajaran, mencari makna teks, atau memahami apa yang mereka dengar dari pelajaran di kelas atau yang dibaca dalam buku dan bahan ajar lain.

Pengetahuan tentang tugas-tugas kognitif yang meliputi pengetahuan kontekstual dan kondisional. Menurut Flavell (1979) pengetahuan metakognitif mencakup pengetahuan bahwa berbagai tugas kognitif itu sulit dan memerlukan sistem kognitif dan strategi-strategi kognitif. Selain mengetahui strategi belajar dan berpikir, juga memerlukan pengetahuan kondisional yaitu siswa harus tahu kapan dan mengapa menggunakan strategistrategi tersebut dengan tepat. Sedangkan pengetahuan diri mencakup pengetahuan tentang kekuatan, kelemahan, minat, bakat, motivasi dalam kaitannya dengan kognisi dan belajar (Gunawan dan Palupi, 2012:111-112).

Konstruksi pengetahuan metakognitif dalam kaitannya dengan pembelajaran agama Hindu mencakup kesadaran akan diri sendiri, aspek keyakinan, dan esensi dalam menghadapi dan memecahkan masalahmasalah yang berhubungan dengan kehidupan religi, sosial, dan kultural. Dalam terjemahan Rgveda X. 56. 1 dinyatakan bahwa "Milikilah mata ketiga (kemampuan memprediksi) dari pengetahuan itu" (Titib, 1996:431). Artinya seorang yang terpelajar dalam konteks metakognitif mampu menyadari dan mengukur kemampuan dirinya sendiri, kelebihan dan kekurangan diri, serta mampu berpikir secara hakiki dan multiperspektif dan multidimensional. Terkait dengan hal tersebut, pengetahuan metakognitif dalam pembelajaran agama Hindu tidak lagi berkutat pada penyajian materi berdasarkan konsep dan klasifikasi, namun menggeneralisasi dalam satu pemahaman utuh dan dipadukan dengan makna filosofis yang bersifat abstrak. Suatu permasalahan akan memotivasi para peserta didik untuk senantiasa berpikir secara multiperspektif dan multidimensional, misalnya dimensi sekala dan niskala (nyata dan abstrak), rasa dan rasio, praktik dan filosofi, dan lain sebagainya.

Konstruksi pengetahuan metakognitif pada dasarnya dilakukan untuk mencapai citacita dari pendidikan agama Hindu itu sendiri. Pendidikan agama pada hakikatnya berupaya untuk memekarkan nilai-nilai kemanusiaan yang luhur menuju kesempurnaan dan mewujudkan nilai-nilai yang baik. Melalui pendidikan agama manusia diajarkan bahasa dan pengetahuan dengan tujuan untuk memuliakan kedudukan manusia, mencerdaskan, membentuk kepribadian dan moral, untuk dapat membedakan yang baik dan buruk, sehingga menjadi manusia yang bijaksana. Dalam Rgveda VIII.3.3 dinyatakan bahwa "mereka yang memiliki kecemerlangan bagaikan kecemerlangannya seperti api, memiliki kekuatan membedakan yang baik dan buruk dan mereka bijaksana" (Titib, 1996:431). Terkait dengan hal tersebut, konstruksi aspek pengetahuan metakognitif dalam pembelajaran agama Hindu harus diupayakan agar terlaksana dengan baik dan berkesinambungan, sehingga tercipta keharmonisan hidup di dalam individu itu sendiri, intern umat beragama, serta antarumat beragama dalam mewujudkan kedamaian hidup. Konstruksi pengetahuan metakognitif dalam pembelajaran agama Hindu bertujuan untuk menanamkan kebiasaan dan keseimbangan berpikir secara multidimensional sebelum melakukan suatu tindakan. Dalam hal ini, kecakapan metakognitif yang diperoleh akan membuat setiap individu peserta didik mampu menempatkan dirinya secara bijak, tanggap dengan pola pikir orang lain, serta mampu menyesuaikan dirinya di tengah-tengah perubahan atau perbedaan lingkungan religi, sosial, dan kultural di tempat dimana dirinya berada. 


\subsection{Strategi Konstruksi Pengetahuan Metakognitif Bagi Peserta Didik}

Pengetahuan metakognitif merupakan pengetahuan yang pada esensinya adalah kemampuan level abstraksi tinggi. Konstruksi pengetahuan level metakognitif harus dimulai dari pencapaian level yang lebih rendah, dalam artian tidak bisa langsung atau sekaligus untuk membuat pemahaman individu semakin terstuktur. Oleh sebab itu, dalam upaya untuk mengkonstruksinya diperlukan beberapa strategi dan tahapan-tahapan yang harus diterapkan secara berkesinambungan. Apabila ditinjau dari sistem dan tujuan dalam pembelajaran secara umum dan pembelajaran agama Hindu khususnya, maka beberapa strategi konstuksi pengetahuan metakognitif yang bisa dilakukan adalah sebagai berikut.

\subsubsection{Implementasi Ajaran Catur Marga}

Catur Marga berasal dari bahasa Sansekerta, dari kata catur yang artinya empat, dan marga yang artinya jalan, cara, atau metode (Tim Penyusun, 2006:61). Catur Marga merupakan ajaran yang berisikan tentang empat cara atau jalan untuk mendekatkan diri atau menuju Tuhan. Ajaran Catur Marga merupakan suatu konsep ajaran yang memuat empat jalan utama dalam menuju Tuhan (Ida Sang Hyang Widhi Wasa). Adapun keempat jalan tersebut adalah; 1) Bhakti Marga, 2) Karma Marga, 3) Jnana Marga, dan 4) Raja Marga (Adiputra, 2003:23-24). Keempat jalan tersebut merupakan metode atau cara yang dapat dilakukan untuk mendekatkan diri antara manusia dan Tuhan, ataupun mencapai penyatuan antara Atman dengan Ida Sang Hyang Widhi Wasa sebagai Paramaatman.

Ajaran Catur Marga dalam pengertian di atas merupakan konsep secara original. Dalam konteks pendidikan dan pembelajaran, Catur Marga merupakan pola konstruktivisme Hindu yang secara bertahap membentuk kecakapan peserta didik. Jayendra (2017:74) menyatakan bahwa apabila dicermati, sesungguhnya ajaran Catur Marga tersebut bukanlah sebuah ajaran yang keempat bagiannya merupakan metode pendekatan diri menuju Tuhan yang terpisah-pisah, melainkan empat tahapan berjenjang dalam mencapai pemahaman akan hakikat Tuhan, hakikat kesemestaan, hakikat bertingkah laku, ritual, dan pemahamanpemahaman tentang pengetahuan hakiki lainnya. Tahapan-tahapan secara berjenjang dalam ajaran Catur Marga membentuk suatu alur yang serupa dengan alur pemikiran atau paradigma konstruktivisme dalam bidang pendidikan.

Tahapan awal konstruksi pengetahuan dimulai dari Bhakti Marga. Bhakti adalah salah satu ajaran yang sangat ditekankan oleh agama Hindu sebagai aktivitas mendekatkan diri pada Ida Sang Hyang Widhi Wasa. Bhakti merupakan perwujudan rasa hormat manusia terhadap Tuhan Yang Maha Esa (Ida Sang Hyang Widhi Wasa) beserta segala manifestasi-Nya. Bhakti memiliki arti filosofis sebagai aktivitas pelayanan yang tulus ikhlas sebagai bentuk penghormatan pada Sang Pencipta. Dalam konteks filosofis dan teologis, Bhakti Marga merupakan jalan pendekatan kepada Tuhan melalui kebaikan dan kesujudan yang tulus dan terus menerus (Sudharta dan Atmadja, 2001:24). Cakupan pengertian Bhakti Marga tidak hanya terbatas pada penyembahan, namun juga adalah kegiatan yang tulus ikhlas dalam rangka memegang dan memelihara kebajikan bagi umat manusia dalam bertingkah laku yang luhur sebagai umat beragama.

Bhakti Marga apabila diarahkan dalam konteks pembelajaran merupakan strategi yang tepat dalam rangka menumbuhkan ketaatan dan kepatuhan. Pada tahapan Bhakti Marga, seorang pembelajar dibentuk perilakunya melalui aktivitas-aktivitas behavioral yang sifatnya berulang tetap sebagai stimulus. Dalam hal ini, aktivitas- aktivitas behavioral tersebut lebih diarahkan untuk mendasari pembentukan kecakapan kognitif. Tujuannya 
adalah membentuk keyakinan yang didasari oleh ketaatan dan kebiasaan dengan serangkaian pengalaman-pengalaman belajar yang berkesan sebagai dasar dalam membentuk konstruksi pengetahuan (Jayendra, 2017:80). Dengan kata lain perilaku pada tahapan ini dibentuk melalui proses automatisasi sesuai prinsip-prinsip behavioristik.

Tahapan selanjutnya adalah Karma Marga. Karma Marga adalah cara atau jalan untuk mendekatkan diri pada Ida Sang Hyang Widhi Wasa dengan melakukan perbuatan mulia dan bermanfaat tanpa pamrih (Sudharta dan Atmadja, 2001:24). Jalan karma dilakukan demi peningkatan kualitas diri, dengan melakukan hal-hal yang bermanfaat, baik bagi diri sendiri maupun bagi kebaikan orang banyak. Karma Marga dalam konteks pembelajaran masih berpusat pada aktivitasaktivitas behavioral yang sifatnya berulang tetap. Perbedaannya dengan tahapan Bhakti Marga adalah pada tahapan ini justru aktivitas dan perilaku peserta didik diarahkan sebagai interpretasi dan aktualisasi dari nilai-nilai keyakinan dan ketaatan yang telah ditanamkan sebelumnya. Automatisasi perilaku lebih diarahkan pada pembentukan kedisiplinan dan keikhlasan sebagai bagian dari kepribadian.

Tahapan ketiga adalah Jnana Marga. Jnana dalam bahasa Sansekerta berarti pengetahuan (Tim Penyusun, 2006:50). Jnana Marga merupakan jalan mendekatkan diri kepada Ida Sang Hyang Widhi Wasa melalui mempelajari pengetahuan ataupun mengabdikan diri pada pengetahuan. Pengetahuan yang dipelajari dan diamalkan bersumber dari kitab suci Veda, baik pengetahuan dalam kategori para widya (bersifat kerohanian) maupun apara widya (bersifat keduniawian/Jayendra, 2017:77-78). Dalam ranah pembelajaran, konsep Jnana Marga mulai mengarahkan peserta didik untuk berpikir secara multidimensional dengan bereksperimen, mengambil perbandingan (komparatif), asas kebalikan dalam berpikir, serta mengkaji suatu permasalahan melalui multiperspektif.

Tahap akhir dari konstruksi pengetahuan metakognitif adalan Raja Marga. Raja Marga sendiri sesungguhnya merupakan cara atau jalan mendekatkan diri kepada Ida Sang Hyang Widhi Wasa melalui berpantang diri, mengendalikan indriya-indriya, dan melaksanakan tapa, brata, yoga, dan samadhi. Dalam hal ini, umat Hindu dituntut untuk mampu melepaskan diri dari segala macam ikatan dan hawa nafsu yang membelenggu dirinya untuk mendapatkan pencerahan dan ketenangan batin. Dalam ranah pembelajaran, penekanan tahap Raja Marga lebih pada olah emosional dan spiritual yang menjadi satu kesatuan dengan hasil konstruksi tiga tahapan sebelumnya. Pada tahapan ini, pengendalian diri (self control) sudah terbentuk, dan menjadi bagian dari karakter dan kepribadian.

Tahapan Raja Marga merupakan final dari proses karakterisasi individu peserta didik. Generalisasi pencapaian dari keempat tahapan inilah yang menjadi pengetahuan metakognitif. Boleh dikatakan bahwa pencapaian esensi dari keempat tahapan Catur Marga sudah merupakan pola konstruksi pengetahuan metakognitif yang terdapat dalam pembelajaran agama Hindu. Dalam hal ini, kecerdasan dan kecakapan individu diarahkan untuk hal-hal yang bermanfaat dan dapat membawa keharmonisan dalam kehidupan bersama.

\subsubsection{Konstruksi Dimensi Pengetahuan Faktual, Konseptual, Dan Prosedural} Pencapaian konstruksi aspek pengetahuan metakognitif pada setiap individu secara mantap tidak dapat dilepaskan dari tahapan dimensi pengetahuan lainnya. Dalam pola Taksonomi Bloom Revisi, tiga level pencapaian dimensi pengetahuan sebelum pengetahuan metakognitif adalah pengetahuan faktual, konseptual, dan prosedural. Tanpa melalui tiga pencapaian level dimensi 
pengetahuan tersebut, pengetahuan metakognitif tidak akan terkonstruksi secara efektif dan sistematis.

Pengetahuan faktual pada umumnya merupakan abstraksi level rendah (Widodo, 2005:63). Pengetahuan faktual berisikan elemen-elemen dasar yang harus diketahui peserta didik jika mereka akan mempelajari suatu disiplin ilmu atau menyelesaikan masalah dalam disiplin ilmu tersebut (Gunawan dan Palupi, 2012:109). Pada dasarnya, pengetahuan faktual diperoleh melalui pengamatan langsung. Dalam hal ini peserta didik mampu menguraikan suatu konsep atau jalannya suatu alur peristiwa berdasarkan fakta-fakta konkrit yang tersaji di lapangan. Misalnya menyebutkan dan menguraikan sarana upacara yadnya, prosesi atau jalannya suatu upacara yadnya, dan tujuan umum dari penyelenggaraan upacara yadnya tersebut.

Pengetahuan konseptual mencakup pengetahuan tentang kategori, klasifikasi, dan hubungan antara dua atau lebih kategori pengetahuan yang lebih kompleks dan tertata. Pengetahuan konseptual meliputi skema, model, mental, dan teori yang mempresentasikan pengetahuan manusia tentang bagaimana suatu materi kajian ditata dan distrukturkan, bagaimana bagian-bagian informasi saling berkaitan secara sistematis, dan bagaimana bagian-bagian ini berfungsi bersama (Gunawan dan Palupi, 2012:110). Menurut Widodo (2005:62), menyatakan bahwa pengetahuan konseptual mencakup klasifikasi, kategori, prinsip, generalisasi, teori, model, dan struktur.

Pengetahuan konseptual dalam ranah pembelajaran agama Hindu mengarahkan peserta didik untuk lebih memahami maknamakna dibalik setiap tindakan religius yang dilakukan. Misalnya dalam suatu upacara yadnya para peserta didik diajak untuk menggali nilai Susila (etika) yang terkandung dalam setiap ritualnya. Para peserta didik lalu menemukan bahwa nilai Susila yang terkandung saat berlangsungnya prosesi upacara adalah saat umat Hindu dilarang berbicara, apalagi yang cenderung kasar atau tidak senonoh, karena sesungguhnya hal itu dilarang untuk mendisiplinkan perilaku, baik dalam upacara, maupun dalam kehidupan sehari-hari.

Pengetahuan prosedural mencakup pengetahuan tentang bagaimana mengerjakan sesuatu. Seringkali pengetahuan prosedural berisi tentang langkah-langkah atau tahapan yang harus diikuti dalam mengerjakan suatu hal tertentu (Widodo, 2005:64). Implementasi pengetahuan prosedural mengarahkan peserta didik tidak hanya sebatas mampu menguraikan fakta-fakta di lapangan beserta maksud dan tujuannya secara konseptual, namun juga mampu memahami dan menganalisis syaratsyarat, serta menciptakan atau mendesain kondisi-kondisi untuk mencapai tujuan yang telah ditetapkan secara konseptual. Dalam hal ini, proses kecakapan kognitif diarahkan agar pengetahuan yang diperoleh mampu lebih digeneralisasikan menuju satu kesatuan yang utuh.

Pengetahuan prosedural dalam pembelajaran agama Hindu dapat ditanamkan melalui keterlibatan atau partisipasi aktif setiap peserta didik dalam kegiatan. Salah satu strategi yang diterapkan dalam konstruksi pengetahuan prosedural adalah melalui belajar partisipatif. Belajar partisipatif merupakan cara belajar yang dilakukan dengan memprioritaskan keterlibatan peserta didik dalam kegiatan-kegiatan agama, sosial, dan budaya, baik yang berlangsung di sekolah, maupun yang berlangsung di lingkungan masyarakatnya. Misalnya dalam menyambut persembahyangan yang akan dilangsungkan di sekolah. Dalam hal ini, melalui bimbingan dan kontrol dari guru, para peserta didik diberikan tugas-tugas prosedural, misalnya menyiapkan bahan-bahan upakara, majejahitan (merangkai janur), matanding (merangkai banten), hingga 
pada pelaksanaan teknis persembahyangan. Tujuannya adalah agar peserta didik memperoleh pengetahuan mengenai syaratsyarat suksesnya suatu persembahyangan melalui setiap prosedur yang dilakukan. Misalnya mengapa harus menggunakan bunga, mengapa harus menggunakan tirtha (air suci), dan sebagainya.

Sehubungan dengan hal tersebut, dalam pelaksanaan teknisnya, peserta didik juga akan mendapat pengetahuan, misalnya mampu menganalisis mengapa persembahyangan harus dilakukan pagi hari, bagaimana langkahlangkah prosesinya, dan sebagainya. Dengan keterlibatan seperti ini, setiap individu peserta didikakanmemahamidanmenghayatijalannya suatu kegiatan upacara persembahyangan sehingga memiliki kesan pengalaman belajar yang kuat dan pengalaman tersebut dapat diaplikasikan dalam penyelenggaraan kegiatan-kegiatan serupa di lain kesempatan. Pencapaian pengetahuan level prosedural yang tertinggi adalah mampu mendesain dan merancang sendiri suatu dengan memobilisasi sumber daya yang ada, serta mengkondisikan berbagai situasi untuk mencapai tujuan yang telah ditetapkan.

Melalui konstruksi pengetahuan faktual, konseptual, dan prosedural yang mantap, maka konstruksi pengetahuan metakognitif akan lebih terstruktur dan tersistematisasi dengan baik dalam diri peserta didik. Melalui tahapan-tahapan pencapaian kompetensi aspek pengetahuan secara bertahap dari faktual, konseptual, prosedural, hingga pencapaian level pengetahuan metakognitif, para peserta didik diarahkan secara bertahap untuk melihat kembali konstruksi sistem pengetahuannya dan cara berpikirnya, mulai dari tingkat dasar hingga melahirkan kompleksitas pemahaman, logika, keyakinan, dan kesadaran hingga melahirkan ciri khas dari penguasaan level pengetahuan metakognitif, yakni kebijaksanaan sebagai bagian dari karakter individu peserta didik.

\subsubsection{Belajar Komparatif}

Belajar komparatif merupakan salah satu strategi yang dapat dipergunakan untuk memperkuat konstruksi pengetahuan metakognitif peserta didik. Belajar komparatif merupakan belajar dengan cara membandingkan variabel-variabel yang terdapat pada lebih dari satu permasalahan atau fenomena yang serupa. Tujuan utama dari studi komparatif adalah membandingkan persamaan dan perbedaan dari fakta atau peristiwa yang terjadi dalam kehidupan religi dan sosio-kultural masyarakat, serta yang terpenting menemukan pondasi esensial yang menciptakan persamaan dan perbedaan tersebut.

Belajar komparatif dalam pembelajaran agama Hindu sangat berguna bagi peserta didik dalam upaya konstruksi pengetahuan metakognitifnya. Misalnya menyajikan fakta tentang upacara Ngaben sebagai salah satu ritual yang tergolong Pitra Yadnya. Guru dapat menyajikan fakta bahwa ada beberapa daerah yang dominan melaksanakan upacara Ngaben tersebut dengan pembakaran jenazah, namun di daerah lain ada pula yang melakukan Ngaben dengan Mendem Sawa (penguburan jenazah). Melalui fakta yang disajikan tersebut, para peserta didik diarahkan untuk melakukan analisis secara individual ataupun berdiskusi secara berkelompok. Tujuan sesungguhnya dari penyajian fakta tentang upacara Ngaben tersebut adalah agar para peserta didik mampu menemukan esensi yang pokok atau hal-hal yang prinsip dari perbedaan tata cara upacara Ngaben tersebut. Hal yang sama juga berlaku bagi fenomena-fenomena yang lainnya.

Belajar komparatif akan sangat efektif dilakukan apabila tingkat usia dan pemikiran peserta didik sudah mencapai kematangan yang cukup. Dalam artian pola ini bisa dilakukan secara efektif jika tingkat kematangan berpikirnya sudah mencapai tahap berpikir abstrak. Menurut Piaget, tahapan ini disebut Tahap Operasional 
Formal. Piaget (dalam Syah, 2002:75) menyatakan bahwa Tahap Operasional Formal dimulai pada usia di atas 11 tahun dengan ciri-ciri generalisasi pemikiran yang lengkap, berpikir proporsional, kemampuan memecahkan masalah abstrak dan hipotesis, berkembangnya idealisme yang kuat, berpikir kombinasional. Usia di bawah itu tidak akan efektif, karena tahap pencapaian level belajar peserta didik masih berorientasi pada level pengetahuan faktual dan konseptual.

\subsubsection{Belajar Partisipatif}

Belajar partisipatif merupakan salah satu strategi yang juga cukup penting diimplementasikan dalam rangka mematangkan pengetahuan metakognitif pada peserta didik. Belajar partisipatif merupakan strategi belajar melalui partisipasi atau peran serta peserta didik dalam kegiatankegiatan di masyarakat, terutama yang menyangkut kegiatan keagamaan, sosial, dan budaya. Sekilas, belajar partisipatif mirip dengan proses konstruksi pengetahuan level prosedural, namun perbedaannya adalah dalam hal ini, peserta didik belajar dari masyarakat untuk menyesuaikan pengetahuan yang dimiliki sesuai kebutuhan dan tuntutan masyarakat.

Menurut Linton (dalam Hartomo, 2004:88), masyarakat adalah setiap kelompok manusia yang telah cukup lama hidup dan bekerja sama, sehingga mereka itu dapat mengorganisasikan dirinya dan berpikir tentang dirinya sebagai satu kesatuan sosial dalam batas-batas tertentu. Masyarakat dalam hal ini berfungsi sebagai tempat peserta didik bergaul dan bersosialisasi. Dalam setiap masyarakat, pewarisan budaya terjadi melalui proses sosialisasi. Individu sebagai anggota masyarakat mendapat pembentukan sikap untuk berperilaku sesuai dengan perilaku masyarakat (Simanjuntak, 2003:167). Keterlibatan para peserta didik dalam kegiatan sosial keagamaan dan budaya di masyarakat memiliki peran yang sangat penting dalam mematangkan pengetahuan prosedural sekaligus metakognitifnya. Menurut Vygotsky (dalam Abidin, 2012:3-4), pembelajar akan lebih baik tidak belajar dalam isolasi. Sebaliknya belajar sangat dipengaruhi oleh interaksi sosial, yang terjadi dalam konteks yang bermakna. Interaksi sosial dengan yang lebih berpengetahuan atau berpengalaman dan lingkungan mereka secara signifikan berdampak pada cara mereka berpikir dan menafsirkan situasi.

Vygotsky (dalam Baharuddin dan Wahyuni, 2010:124) juga mengemukakan bahwa masa belajar dimulai ketika individu dalam perkembangan yang disebut zone proximal, yaitu suatu tingkat yang dicapai oleh seorang anak ketika ia melakukan perilaku sosial. Individu akan belajar mengenai berbagai konsep paling baik apabila konsep itu berada dalam zona perkembangan terdekat mereka. Zone proximal juga dapat diartikan sebagai seorang pembelajar yang tidak dapat melakukan sesuatu sendiri, tetapi memerlukan bantuan kelompok atau orang dewasa. Seorang pembelajar mengembangkan kecerdasannya berdasarkan konsep internalisasi atau interpretasi sendiri dari aktivitas yang terjadi dalam pengaturan sosial. Komunikasi yang terjadi dalam pengaturan ini dengan orang yang lebih berpengetahuan atau berpengalaman akan sangat membantu seorang pembelajar membangun pemahaman konsep yang mantap namun luwes dan tidak kaku. Sehubungan dengan hal tersebut, menurut Piaget dan Vygotsky (dalam Baharudin dan Wahyuni, 2010:128) lingkungan sosial menjadikan kelompok belajar sebagai tempat untuk mendapatkan pengetahuan, mengeksplorasi pengetahuan, dan menantang pengetahuan yang dimiliki. Lebih jauh, Dewey (dalam Rohman, 2013:130) menyatakan bahwa dalam tahapan perkembangan kepribadian yang luwes berpikir sebagai berikut. 
1. Tahap Premoral atau Preconventional, dimana tingkah laku seseorang didorong oleh desakan yang bersifat fisikal atau sosial.

2. Tahap Conventional, dimana individu pembelajar mulai bisa menerima nilai dengan sedikit kritis kepada kriteria kelompoknya.

3. Tahap Autonomous, dimana pembelajar sudah mulai bisa berbuat atau bertingkah laku sesuai dengan akal pikiran dan pertimbangan dirinya sendiri, tidak sepenuhnya menerima kriteria kelompoknya. Menurut Piaget, pada tahapan autonomous, aturan dipandang sebagai persetujuan bersama secara timbal balik, dapat dipelihara, dan dapat diubah sesuai kebutuhan kolektif (Rohman, 2013:131).

Belajar partisipatif dalam masyarakat dapat diusahakan melalui peran serta orang tua dalam mengenalkan anak didik pada lingkungan religi dan sosio-kultural masyarakat. Bisa pula diupayakan melalui penugasan yang dilakukan oleh guru di sekolah dengan evaluasi berupa laporan yang disusun dan didiskusikan bersama dalam pembelajaran di kelas. Melalui pembelajaran partisipatif, diharapkan peserta didik mampu semakin bijak dengan memadukan pengalaman belajar teoritis dan praktisnya dalam upaya untuk memaksimalkan peran sertanya di masyarakat di masa-masa mendatang.

\subsection{Implikasi Konstruksi Pengetahuan Metakognitif Bagi Pembentukan Karakter}

Pengetahuan metakognitif yang telah terkonstruksi dengan baik dan mantap dalam diri setiap individu peserta didik akan menjadi bagian dari karakter dan pola pikirnya. Hal ini sangat penting dalam pergaulannya dalam kehidupan religi dan sosio-kulturalnya di masyarakat. Implikasi konstruksi pengetahuan metakognitif yang utama bagi karakter peserta didik tampak dalam kepribadiannya secara individu dan kepribadiannya kehidupan bermasyarakat.

Secara individu, pengetahuan metakognitif berimplikasi pada penguatan sraddha dan bhakti, cakap dalam merumuskan strategi dan mengambil keputusan, serta kreatif dalam menganalisis berbagai alternatif guna pemecahan berbagai masalah. Berkaitan dengan hal tersebut, proses berpikir yang kombinasional atau multidimensi sangat penting untuk membantu pembelajar dalam menafsirkan realitas-realitas ganda. Melalui konstruksi cara berpikir yang multidimensional, berimplikasi pula terhadap timbulnya proses berpikir kreatif. Menurut Irham dan Wiyani (2013:47-48), tahapantahapan berpikir kreatif adalah sebagai berikut.

1. Tahap Persiapan, yaitu ketika bahanbahan atau pengetahuan dikumpulkan dan disusun terus-menerus dalam memori individu.

2. Tahap Inkubasi, yaitu ketika atas dasar bahan-bahan yang terkumpul lama kemudian memunculkan aspek-aspek pernyataan yang berbeda dan kreatif, tetapi masih samar-samar.

3. Tahap Insight (pemahaman), yaitu ketika pemahaman dan penemuan hal yang berbeda dan terjadi sangat tibatiba.

Dalam konteks pembelajaran agama Hindu, berpikir kombinasional dan multidimensional berimplikasi pada penguatan sraddha dan bhakti peserta didik. Keyakinan yang sebelumnya ditanamkan secara behavioral akan diperkuat dengan pengetahuan akan esensi makna filosofis dari setiap tindakan-tindakan religius yang dilakukan. Keterpaduan antara "rasa" dengan "rasio" akan membuatnya cakap dalam menyikapi fenomena-fenomena yang terkait dengan masalah kehidupan beragama dan berbudaya. Implikasi dari terkonstruksinya 
pengetahuan metakognitif dalam aspek kehidupan bermasyarakat akan tampak dalam kepribadian individu yang mampu membaca dan menyesuaikan pola pikirnya dengan orang banyak dalam interaksinya seharihari. Ciri dari hal ini adalam dimana individu mampu menangkap makna dan mengukur kemampuan lawan bicaranya serta merespons sesuai dengan level kemampuan lawan bicaranya tersebut. Dalam terjemahan Rgveda IX. 87. 3 dinyatakan bahwa "seorang sarjana mengetahui rahasia (makna) pembicaraan" (Titib, 1996:431).

Dalam hal ini, pengetahuan metakognitif mengalami proses pematangan melalui penyesuaian-penyesuaian sesuai dengan norma-norma atau dresta desa yang berlaku dalam kehidupan religi dan sosiokultural masyarakat tempatnya berada. Dalam artian peserta didik dilatih untuk menjadi pribadi yang mampu berpikir dan bertindak secara luwes dan terbuka dalam menerima perbedaan, sesuai dengan ciri khas perilaku metakognitif. Piaget (dalam Baharuddin dan Wahyuni, 2010:118) menyatakan manusia selalu berusaha untuk menyesuaikan diri dengan lingkungannya. Manusia cenderung mengorganisasikan tingkah laku dan pikirannya. Hal itu mengakibatkan adanya sejumlah struktur psikologis yang berbeda bentuknya pada setiap fase atau tingkatan perkembangan tingkah laku dan kegiatan berpikir manusia. Dengan demikian, pikiran memiliki suatu struktur, yaitu skema yang berfungsi melakukan adaptasi dengan lingkungan dan menata lingkungan tersebut secara intelektual.

Terkait dengan hal tersebut, implikasi pengetahuan metakognitif yang terkonstruksi dengan baik mengarahkan peserta didik tidak hanya mampu sebatas merencanakan (planning) dan merumuskan (generating), namun pencapaian hasil olah metakognisi yang tertinggi adalah mampu membuat atau menciptakan (create) berdasarkan pemahaman-pemahaman esensial yang dikuasai. Dalam pembelajaran agama Hindu, kemampuan level ini sangat penting untuk menciptakan inovasi-inovasi baru dalam tatanan ritual keagamaan. Hal ini dimaksudkan bukan untuk mendekonstruksi tatanan yang ada, melainkan untuk memunculkan suatu desain ritual yang tidak monoton, efektif dan efisien, serta mampu menarik dan menggugah masyarakat dengan tetap berpegang teguh pada esensi yang ada. Melalui pengetahuan metakognitif yang terkonstruksi dengan baik sebagai bagian dari karakter peserta didik, diharapkan mampu mengimplementasikan kecakapannya dalam menciptakan tatanan masyarakat Hindu yang bijaksana, religius, dan harmonis.

\section{SIMPULAN}

Konstruksi pengetahuan level metakognitif merupakan kemampuan untuk mengetahui dan menyadari diri sendiri, dan mencakup pula kecakapan strategi kognitif melalui berpikir multiperspektif, serta multidimensional. Dalam pembelajaran agama Hindu, konstruksi pengetahuan metakognitif sangat berguna bagi rekonstruksi dan rekondisi tatanan religi dan sosio kultural masyarakat Hindu. Dalam artian bukan untuk mendekonstruksi, melainkan kedepannya untuk menciptakan masyarakat yang inovatif, kreatif, kritis, dan paham akan makna esensial dari setiap aktivitas religius.

Kemampuan ini dapat dikonstruksi melalui beberapa strategi atnara lain, implementasi ajaran Catur Marga, konstruksi dimensi pengetahuan faktual, konseptual, dan prosedural, belajar komparatif, serta belajar partisipatif. Satu hal yang perlu disadari bahwa pengetahuan metakognitif sejatinya sudah ada dalam diri setiap individu peserta didik, namun belum terkonstruksi, terstruktur, dan tersistematisasi dengan baik. Oleh sebab itulah perlu diimplementasikan beberapa rumusan strategi agar kecakapan level kognitif 
mampu terkonstruksi dengan baik. Konstruksi pengetahuan metakognitif akan menjadikan setiap individu peserta didik menjadi diri yang bijaksana dan berguna bagi dirinya dalam kehidupan religi dan sosio-kultural masyarakat Hindu di masa-masa mendatang.

\section{DAFTAR PUSTAKA}

Adiputra, I Gede Rudia. 2003. Pengetahuan Dasar Agama Hindu. Jakarta: STAH Dharma Nusantara.

Baharuddin, H dan Esa Nur Wahyuni. 2010. Teori Belajar dan Pembelajaran. Yogyakarta: Ar-ruzz Media.

Gunawan, Imam dan Anggarini Retno Palupi. 2012. "Taksonomi Bloom-Revisi Ranah Kognitif: Kerangka Landasan Untuk Pembelajaran, Pengajaran, dan Penilaian", dalam Jurnal Pendidikan Dasar dan Pembelajaran, Volume 2, No. 02, 2012. IKIP PGRI Madiun http:// e-journal.ikippgrimadiun.ac.id/index. php/PE/article/view/50/47 (diakses 12 Juni 2017).

Hartomo, H dan Arnicun Aziz. 2004. Ilmu Sosial Dasar. Jakarta: Bumi Aksara.

Indarini, Endang dkk. 2013. "Pengetahuan Metakognitif Untuk Pendidik dan Peserta Didik", dalam Jurnal Satya Widya, Volume 29, No.1. Juni 2013 http://ejournal.uksw.edu/satyawidya/ article/view/124/112 (diakses 12 Juni 2017).

Irham, M. \& Wiyani, N. A. 2013. Psikologi Pendidikan: Teori dan aplikasi dalam Proses Pembelajaran. Yogjakarta: Arruzz Media.

Jayendra, Putu Sabda. 2017. “Ajaran Catur Marga Dalam Tinjauan Konstruktivisme Dan Relevansinya Dengan Empat Pilar Pendidikan UNESCO”, dalam Jurnal Vidya Samhita, Volume 3, No. 1, Januari - Februari 2017. Institut Hindu Dharma Negeri Denpasar.
Mahfud, Choirul. 2008. Pendidikan Multikultural. Yogyakarta: Pustaka Pelajar.

Rohman, Arif. 2011. Memahami Pendidikan dan Ilmu Pendidikan. Yogyakarta: Laksbang Mediatama.

Rohman, Arif. 2013. Memahami Ilmu Pendidikan. Yogyakarta: Aswaja Pressindo.

Sadulloh, Uyoh. 2010. Pedagogik (Ilmu Mendidik). Bandung: Alfabeta.

Sudharta, Tjok. Rai dan I.B. Oka Punia Atmaja. 2001. Upadesa tentang Ajaran-ajaran Agama Hindu. Surabaya: Paramita.

Syah, Muhibbin. 2002. Psikologi Pendidikan Dengan Pendekatan Baru. Bandung: Remaja Rosdakarya.

Tim Penyusun. 2006. Kamus Istilah Agama Hindu. Denpasar: Pemerintah Provinsi Bali.

Titib, I Made. 1996. Veda Sabda Suci Pedoman Praktis Kehidupan. Surabaya: Paramita.

Widodo, Ari. 2005. Taksonomi Tujuan Pembelajaran Didaktis. Bandung: Universitas Pendidikan Indonesia. 